\title{
Perbedaan Jumlah Sel Neuron Cerebrum dan Cerebellum Mus musculus pada Kehamilan Remaja dan Dewasa
}

\author{
Tri Purwanti $^{1 *}$, Widjiati ${ }^{2}$, Muhammad Miftahussurur ${ }^{3}$ \\ Master degree of Reproductive Health Science, Faculty of Medicine, Universitas \\ Airlangga, Surabaya 60285, Indonesia ${ }^{1}$ \\ Department of Embryology, Faculty of Medicine, Universitas Airlangga, Dr. Soetomo \\ Teaching Hospital, Surabaya 60285, Indonesia ${ }^{2}$ \\ Department of Internal Medicine, Faculty of Medicine, Universitas Airlangga, Dr. \\ Soetomo Teaching Hospital, Surabaya 60285, Indonesia ${ }^{3}$ \\ *e-mail: firabiku@gmail.com
}

\begin{abstract}
Abstrak
Kehamilan remaja berkontribusi terhadap stress emosional lebih tinggi dibandingkan dengan wanita dewasa. Kehamilan pada remaja akan memicu pemikiran negatif dan perasaan takut sehingga menjadi akar penyebab reaksi stres. Timbulnya stress akan memicu terjadi aktivitas HPA Axis dan dikeluarkannya corticotrophin releasing hormone (CRH) oleh nukleus paraventrikular dari hipotalamus, kemudian merangsang produksi dari adrencorticotropic hormone (ACTH) oleh kelenjar pituitary anterior. ACTH ini akan merangsang glukokortikoid (kortisol) dari kelenjar adrenal cortex meningkatkan produksi CRH di plasenta dan memberikan efek peningkatan kortisol di maternal, begitupun juga jumlah kortisol di fetus akan meningkat pula karena mengikuti blood placenta barrier. Hal ini mempengaruhi pertumbuhan dan perkembangan otak janin, sehingga pada proses proliferasi dan diferensiasi, migrasi, organisasi dan sinaptogenesis serta mielinisasi pada sel otak. Tumbuh kembang otak menurun sehingga mempengaruhi jumlah sel neuron. Penelitian ini bertujuan menganalisis perbedaan jumlah sel neuron pada cerebrum dan cerebellum Mus musculus baru lahir pada kehamilan remaja dan dewasa. Jenis penelitian yang dilakukan adalah eksperimen laboratorium menggunakan rancangan penelitian yaitu post test only control group design. Pembagian kelompok penelitian terdiri dari dua kelompok yaitu kelompok kehamilan remaja dan dewasa masingmasing 16 ekor. Pengambilan sampel pemeriksaan adalah dengan mengambil masing-masing 3 anak dari induk dengan bobot terberat, sedang dan terendah. Kemudian anak Mus musculus dikorbankan dengan pembiusan dan dekapitasi, kemudian dibuat preparat Hematoksilin-Eosin dari otak anak. Langkah selanjutnya pemeriksaan Hematoksilin-Eosin untuk menghitung jumlah sel neuron pada cerebrum dan cerebellum dengan analisa uji Independent $T$ menunjukkan perbedaan bermakna antara kelompok kontrol dan perlakuan dengan nilai $p=0,000(p<0,05)$. Kemudian analisa jumlah sel neuron otak menggunakan uji Mann Whitney menunjukkan perbedaan bahwa kelompok kontrol dan kelompok remaja. Simpulan: jumlah sel neuron pada cerebrum dan cerebellum kelompok kehamilan dewasa lebih tinggi dibandingkan dengan kelompok kehamilan remaja.
\end{abstract}

Kata Kunci: kehamilan remaja, sel neuron, stress 


\title{
Differences Between the Cerebrum and Cerebellum Neuron Cells Mus musculus on Teenage Pregnancy and Adulthood
}

\begin{abstract}
Teenage pregnancy contributes to emotional stress higher than adult women Pregnancy in adolescents will trigger negative thoughts and feelings of fear that become the root cause of stress reactions. The onset of stress will trigger the occurrence of Axis HPA activity and the release of corticotrophin releasing hormone $(\mathrm{CRH})$ by the paraventricular nucleus of the hypothalamus, then stimulate the production of adrenocorticotropic hormone (ACTH) by the anterior pituitary gland. ACTH will stimulate glucocorticoids (cortisol) from the adrenal gland cortex to increase the production of $\mathrm{CRH}$ in the placenta and give an effect of increasing cortisol in the maternal, as well as the amount of cortisol in the fetus will also increase because it follows the blood placenta barrier. This affects the growth and development of the fetal brain, so that the process of proliferation and differentiation, migration, organization and synaptogenesis and myelination in brain cells. The growth of the brain decreases which affects the number of neuron cells. This study aims to analyze the differences in the number of neuron cells in the cerebrum and cerebellum Mus musculus newly born in adolescent and adult pregnancy. The division of the study group consisted of two groups, namely the adolescent and adult pregnancy groups each of 16 individuals. Taking the examination sample is by taking each of the 3 children from the parent with the heaviest, medium and lowest weights. Then the Mus musculus children were sacrificed by anesthesia and decapitation, then Hematoxylin-Eosin preparations were made from the child's brain. The next step is to examine Hematoxylin-Eosin to calculate the number of neuron cells in the cerebrum and cerebellum with the analysis of the Independent $T$ test showing significant differences between the control and treatment groups with a value of $p=0,000(p<0.05)$. Then the analysis of the number of brain neuron cells using the Mann Whitney test showed a difference that the control group was higher than the adolescent group.
\end{abstract}

Keywords: teen pregnancy, neuron cells, stress

\section{PENDAHULUAN}

Permasalahan yang masih mendasar baik pada manusia maupun hewan adalah tentang kesehatan reproduksi, akan tetapi dengan adanya kendala etik, maka keberadaan hewan model (hewan coba) diperlukan untuk menjawab permasalahan tersebut melalui penelitian in vivo (Hewitt et al, 1989; Ihedioha et al, 2012). Mencit atau 'Mus musculus' adalah hewan yang paling sering digunakan sebagai model.
Oleh karena dapat mewakili sistem biologis mammalia, maka hewan ini tepat untuk dijadikan sebagai hewan coba (Akbar, 2010). Pemilihan umur hewan coba juga sangat penting karena menentukan arah penelitian.

Umur hewan, harus disesuaikan dengan tujuan penelitian, dimana penentuan umur biologis pada mencit sebagai model untuk dikorelasikan dengan manusia masih menjadi perdebatan. 
Sejumlah penelitian telah dilakukan, antara lain dengan membandingkan berat lensa mata, pertumbuhan gigi geraham, penghitungan lapisan endosteal tibia, pertumbuhan muskulo-skeletal dan penutupan epifisis, dan lain-lain, namun belum diperoleh hasil yang memuaskan (Sengupta, 2013). Penentuan umur reproduktif pada mencit oleh Sengupta (2013) adalah dengan cara mempelajari fase-fase kehidupan dan perilakunya. Beberapa fase tersebut antara lain adalah: rentang hidup antara 2,0-3,5 tahun, fase kematangan seksual atau pubertas mulai umur 6 minggu (40-60 hari), fase pradewasa saat umur $63-70$ hari, fase kematangan sosial saat umur 5-6 bulan (160-180 hari), dan fase penuaan saat umur 15-24 bulan.

Klasifikasi umur menurut Fitria et al (2015) bahwa mencit umur 4-5 minggu dikategorikan sebagai mencit muda (young) yang belum matang seksual (immature); umur 6-7 minggu adalah pradewasa atau dewasa awal (subadult) yang sistem reproduksinya telah berkembang (puberty) namun belum mampu kawin; umur 8-9 minggu merupakan tikus dewasa (adult) yang telah matang seksual dan siap kawin (mature) sehingga tepat dijadikan sebagai hewan model dalam penelitian sistem reproduksi dewasa (Laksmindra, 2015).
Kehamilan remaja, merupakan masalah kesehatan masyarakat yang penting di seluruh dunia, didefinisikan sebagai kehamilan yang terjadi pada usia 10-19 tahun (Curtis, 2016; Lefwitch and Alves, 2017). Diperkirakan bahwa sekitar $11 \%$ dari kelahiran di seluruh dunia adalah remaja berusia 15-19 tahun, dan lebih dari 90\% dari kelahiran ini terjadi di negaranegara berpenghasilan rendah dan menengah (Kirbas et all, 2016). Kehamilan remaja menyumbang angka kematian ibu dan bayi $3 x$ lebih besar. WHO memperkirakan 10.000 ibu melahirkan meninggal setiap tahun di Indonesia salah satunya karena umur perkawinan dibawah 20 tahun (Sarwono, 2011).

Kehamilan pada remaja akan memicu pemikiran yang negatif dan perasaan takut sehingga menjadi akar penyebab reaksi stres. Ibu yang mengalami stres selama hamil mempengaruhi perkembangan fisiologis dan psikologis bayi. Timbulnya stress akan memicu terjadi aktivitas HPA Axis dan dikeluarkannya corticotrophin releasing hormone (CRH) oleh nukleus paraventrikular dari hipotalamus, kemudian akan merangsang produksi dari adrencorticotropic hormone (ACTH) oleh kelenjar pituitary anterior. ACTH ini akan merangsang glukokortikoid (kortisol) dari kelenjar adrenal cortex meningkatkan produksi CRH di plasenta 
Perbedaan Jumlah Sel Neuron Cerebrum dan Cerebellum Mus musculus pada Kehamilan... Tri Purwanti, Widjiati, Muhammad Miftahussurur

yang akan memberikan efek peningkatan kortisol di maternal, begitupun juga jumlah kortisol di fetus akan meningkat pula karena mengikuti blood placenta barrier. Hal ini akan mempengaruhi pertumbuhan dan perkembangan otak janin, sehingga pada proses proliferasi dan diferensiasi, migrasi, organisasi dan sinaptogenesis serta mielinisasi pada sel otak. Tumbuh kembang otak menurun sehingga akan mempengaruhi jumlah sel neuron (Juananda, 2015). Mengingat pentingnya pencegahan kehamilan pada remaja terkait dampak negative yang ditimbulkan, maka perlu dilakukan penelitian lebih lanjut tentang perbedaan jumlah sel neuron pada kehamilan remaja dan dewasa.

\section{BAHAN DAN METODE}

Penelitian ini merupakan penelitian analitik eksperimental laboratorium dengan desain studi post test only control group design menggunakan hewan coba Mus musculus remaja dan dewasa dengan sampel remaja betina remaja sehat, usia 1,5 bulan, dan dewasa sehat usia 3 bulan yang diperoleh dari Veterinaria Laboratorium Penelitian dan Pengujian Terpadu (LPPT) UGM. Pada penelitian ini membandingkan 2 kelompok yaitu kelompok kehamilan remaja dan kelompok kehamilan dewasa.

Kelompok 1 (perlakuan): Mencit
(Mus musculus) betina (dara) berumur 1,5 bulan dilakukan adaptasi lingkungan selama 7 hari. Hari ke 8 dilakukan penyuntikan PMSG dengan dosis 5IU / ekor dan dilakukan penyuntikan HCG pada hari ke 10 dengan dosis 5IU/ ekor kemudian dikawinkan dengan mencit jantan umur 5 bulan. Mencit-mencit tersebut kemudian dipelihara dalam kandang dan diberi makan secara ad-libitum. Kelompok 2 (kontrol) mencit (Mus musculus) betina (dara) berumur 3 bulan dengan dilakukan adaptasi lingkungan selama 7 hari. Hari ke 8 dilakukan penyuntikan PMSG dengan dosis 5IU / ekor dan dilakukan penyuntikan HCG pada hari ke 10 dengan dosis 5IU/ ekor kemudian dikawinkan dengan mencit jantan umur 5 bulan. Mencit-mencit tersebut kemudian dipelihara dalam kandang dan diberi makan secara adlibitum. Pada hari ke 11 pemeriksaan kebuntingan, bila pada vulva mencit betina sudah terlihat sumbat vagina, maka hari tersebut dinyatakan sebagai hari ke-0 kebuntingan. Induk-induk bunting tersebut kemudian dikelompokkan dalam kandang masing-masing 16 ekor sebanyak 2 kelompok, sampai mencit tersebut lahir dan diperiksa otak janin anak.

Variabel terikat pada penelitian ini adalah jumlah sel neuron di cerebrum dan cerebellum Mus musculus baru lahir. Pengukuran jumlah sel neuron terlebih 
ISSN 1978-2071 (Print); ISSN 2580-5967 (Online) Jurnal IImiah Kedokteran Wijaya Kusuma 9(1): 9-20, Maret 2020

dahulu dilakukan pembuatan preparat histologis dari otak. Sedian preparat otak difiksasi dalam formalin $10 \%$ selama kurang lebih 24 jam, dilanjutkan dengan dehidrasi dan clearing, kemudian dilakukan perendaman (embedding) jaringan dalam parafin. Setelah itu, dilakukan pemotongan mikrotom dengan ketebalan irisan 5-7 mikro meter. Setiap sampel dibuat dalam jumlah yang banyak, lalu dipilih sediaan yang paling baik untuk dilakukan pewarnaan Hematosiklin Eosin (HE). Pemeriksaan jaringan diamati di bawah mikroskop dengan 5 lapangan pandang dan pembesaran 400 kali untuk menghitung jumlah sel neuron. Analisa data menggunakan software SPSS. Pengujian normalitas data menggunakan saphiro analisis berikutnya, yaitu analisis parametrik dengna uji Independent $T$ test dan uji Mann Whitney. Penelitian ini menggunakan tingkat kemaknaan sebesar 0,05 .

\section{HASIL}

1. Jumlah sel neuron di Cerebrum anak

\section{Mus musculus}

Tabel 1. Rerata dan simpangan baku jumlah sel neuron di cerebrum Mus musculus baru lahir

\begin{tabular}{ccc}
\hline Kelompok & $\mathbf{N}$ & Mean \pm SD \\
\hline X1 & 16 & $55,94 \pm 18,29$ \\
X2 & 16 & $122,86 \pm 8,81$ \\
\hline
\end{tabular}

X1: perlakuan $\mathrm{X} 2$ : kontrol

Diketahui bahwa hasil rerata dan simpangan baku cerebrum Mus musculus baru lahir pada kelompok kehamilan dewasa (X2) $(122,86 \pm 8,81)$ lebih tinggi dibandingkan dengan kelompok kehamilan remaja (X1) $(55,94 \pm 18,29)$.

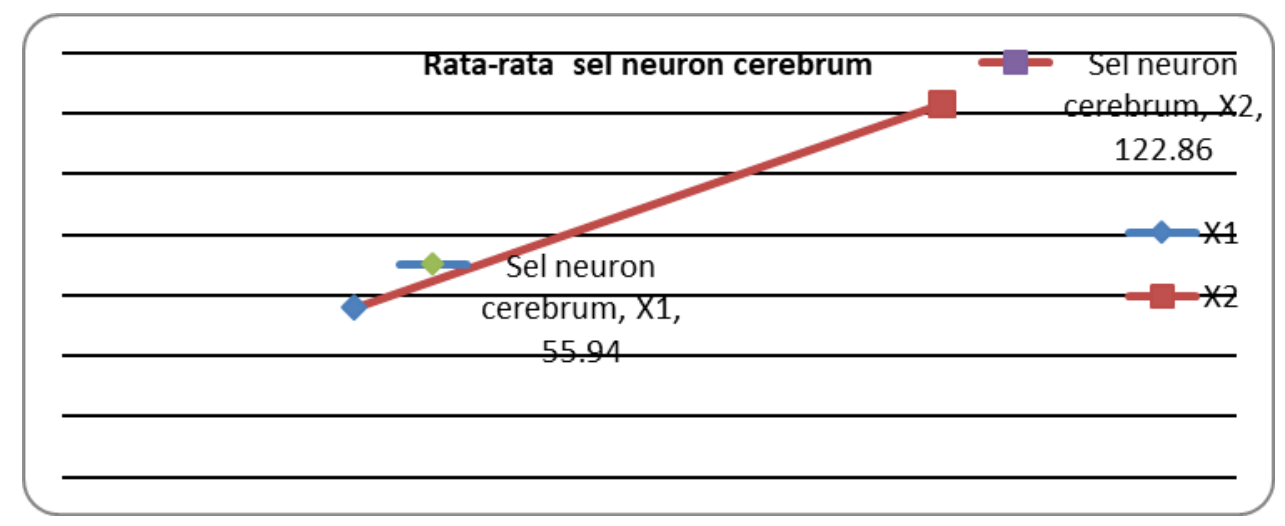

Gambar 1. Diagram line rata-rata jumlah sel neuron cerebrum Mus musculus pada masing-masing kelompok.

Uji normalitas data jumlah sel neuron cerebrum dilakukan dengan uji Shapiro-wilk. Hasil analisis uji Shapiro-wilk disajikan pada tabel di bawah ini:
Tabel 2. Hasil uji Shapiro-wilk jumlah sel neuron cerebrum Mus musculus baru lahir

\begin{tabular}{ccc}
\hline Kelompok & df & Nilai p \\
X1 & 16 & $0,166^{*}$ \\
X2 & 16 & $0,426^{*}$ \\
\hline
\end{tabular}

*Distribusi normal $(p>0,05)$ 
Perbedaan Jumlah Sel Neuron Cerebrum dan Cerebellum Mus musculus pada Kehamilan...

Tri Purwanti, Widjiati, Muhammad Miftahussurur

Diketahui bahwa hasil uji normalitas jumlah sel neuron cerebrum semua kelompok data terdistribusi normal yaitu kelompok perlakuan $(X 1) \quad p=0,166$ dan kelompok kontrol (X2) $p=0,426$. Analisis statistik untuk data berdistribusi normal menggunakan uji perbedaan Independent T-Test. Jika nilai $\mathrm{p}<0,05$ maka terdapat perbedaan yang signifikan. Hasil analisis uji Independent T-Test disajikan pada tabel di bawah ini:

Tabel 3. Hasil uji Independent T-Test jumlah sel neuron cerebrum Mus musculus baru lahir.

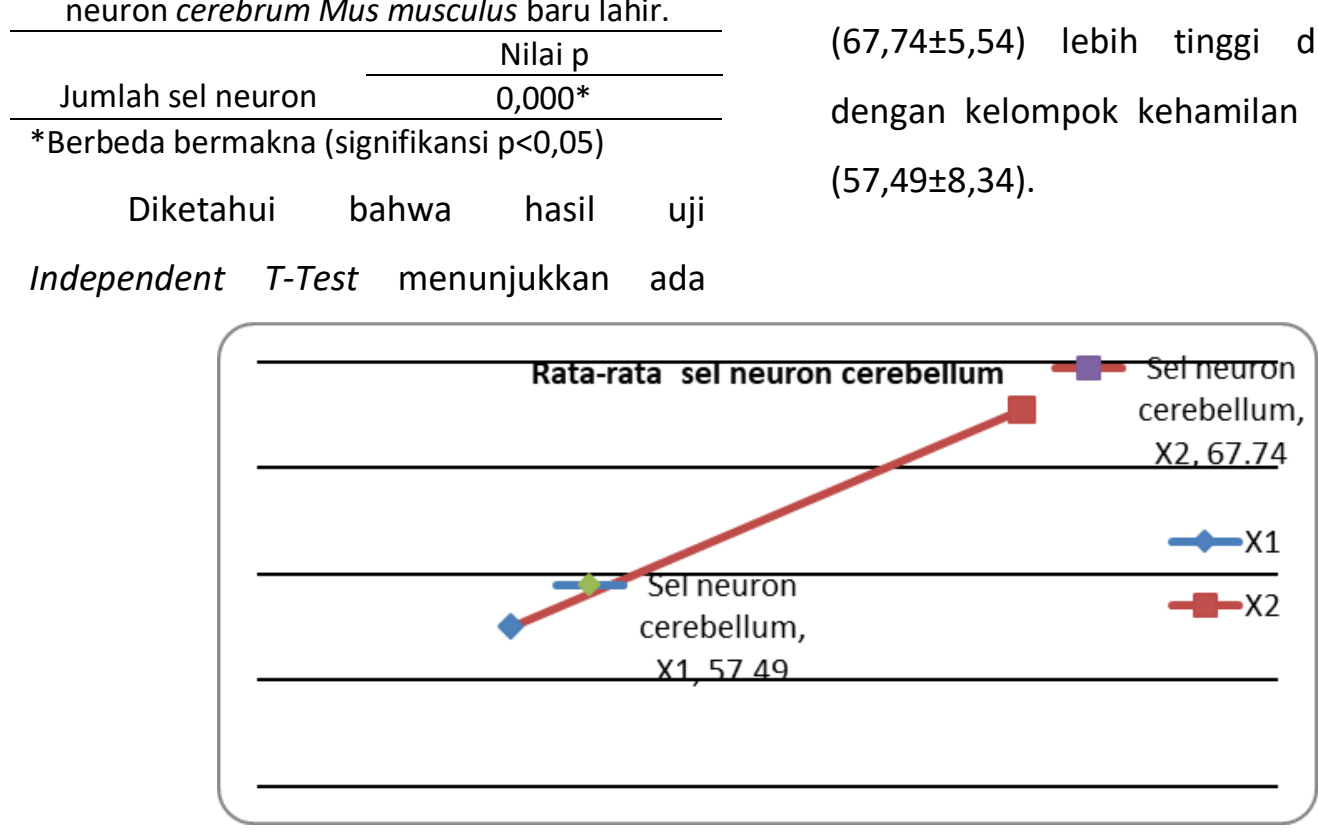

Gambar 2. Diagram batang rata-rata jumlah sel neuron cerebellum Mus musculus pada masing-masing kelompok.

Uji normalitas data ekspresi jumlah sel neuron cerebellum dilakukan dengan uji Shapiro wilk. Hasil analisis uji Shapiro wilk disajikan pada tabel di bawah ini:

Tabel 5. Hasil uji Shapiro wilk jumlah sel neuron cerebellum Mus musculus baru lahir

\begin{tabular}{ccc}
\multicolumn{3}{c}{ Tabel 5. Hasil uji Shapiro wilk jumlah sel neuron cerebellum Mus musculus baru lahir } \\
\hline Kelompok & $\mathbf{d f}$ & Nilai p \\
X1 & 16 & $0,154^{*}$ \\
X2 & 16 & $0,999^{*}$ \\
\hline
\end{tabular}

*Distribusi normal $(p>0,05)$

Diketahui bahwa hasil uji normalitas jumlah sel neuron cerebellum semua kelompok berdistribusi normal dengan nilai $p=0,154$ untuk kelompok perlakuan (X1) 
ISSN 1978-2071 (Print); ISSN 2580-5967 (Online) Jurnal IImiah Kedokteran Wijaya Kusuma 9(1): 9-20, Maret 2020

dan kelompok kontrol (X2) $p=0,999$.

Analisis statistik untuk data berdistribusi normal menggunakan uji perbedaan Independent T-test. Jika nilai $\mathrm{p}<0,05$ maka terdapat perbedaan yang signifikan. Hasil analisis uji Independent T-test disajikan pada tabel di bawah ini:

Tabel 6. Hasil uji Independent T-test jumlah sel neuron cerebellum Mus musculus baru lahir.

Ekspresi jumlah sel
neuron

*Berbeda bermakna (signifikansi $p<0,05$ )

$$
\text { Diketahui bahwa hasil uji }
$$

Independent T-test menunjukkan ada perbedaan bermakna jumlah sel neuron antara kelompok perlakuan dan kontrol di cerebellum $(p=0,000)$.

\section{Jumlah sel neuron otak Mus musculus}

Jumlah sel neuron pada otak Mus musculus dapat dilihat pada Tabel 7 di bawah ini.

Tabel 7. Rerata dan simpangan baku jumlah sel neuron otak Mus musculus

\begin{tabular}{ccc}
\hline Kelompok & $\mathbf{N}$ & Mean \pm SD \\
\hline X1 & 32 & $56,72 \pm 14,01$ \\
X2 & 32 & $95,30 \pm 28,92$ \\
\hline X1: perlakuan & X2: kontrol
\end{tabular}

Diketahui bahwa hasil rerata dan simpangan baku jumlah sel neuron otak Mus musculus baru lahir pada kelompok kehamilan dewasa (X2) $(95,30 \pm 28,92)$ lebih tinggi dibandingkan dengan kelompok kehamilan remaja (X1) $(56,72 \pm 14,01)$.

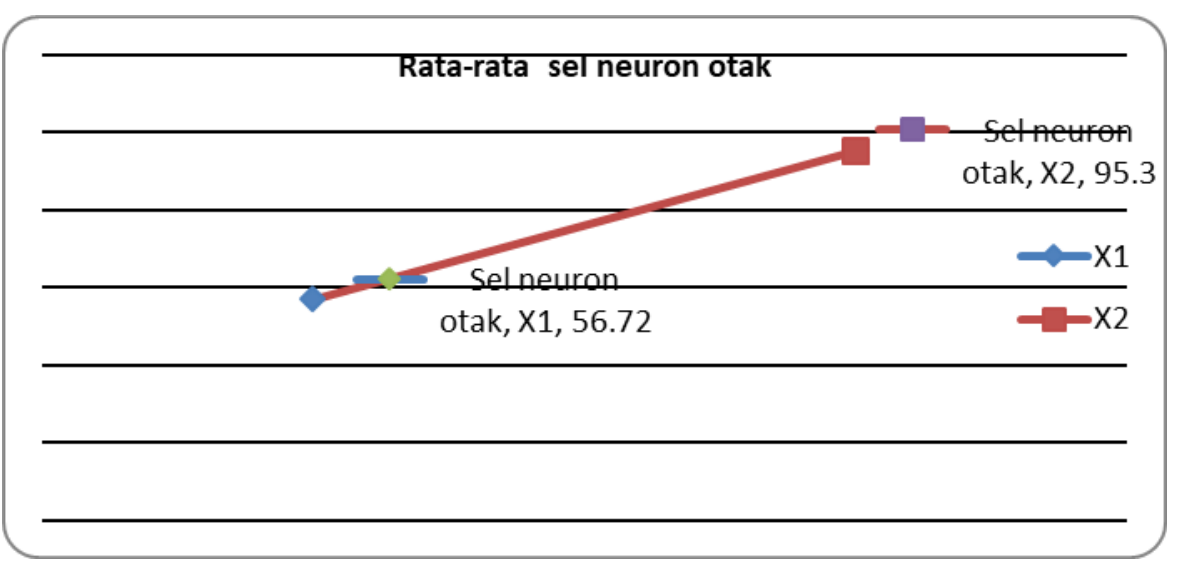

Gambar 3. Diagram batang rata-rata jumlah sel neuron cerebellum Mus musculus pada masing-masing kelompok.

Uji normalitas data jumlah sel wilk. Hasil analisis uji shapiro wilk disajikan neuron otak dilakukan dengan uji shapiro pada tabel di bawah ini:

Tabel 8. Hasil uji shapiro wilk jumlah sel neuron otak Mus musculus baru lahir

\begin{tabular}{ccc}
\hline Kelompok & df & Nilai p \\
\hline $\mathrm{X} 1$ & 32 & $0,127^{*}$ \\
$\mathrm{X} 2$ & 32 & 0,000 \\
\hline
\end{tabular}

*Distribusi normal $(p>0,05)$ 
Perbedaan Jumlah Sel Neuron Cerebrum dan Cerebellum Mus musculus pada Kehamilan... Tri Purwanti, Widjiati, Muhammad Miftahussurur

Diketahui bahwa hasil uji normalitas jumlah sel neuron otak pada kelompok perlakuan (X1) terdistribusi normal dengan nilai $p=0,127$ dan data tidak berdistribusi normal dengan nilai $p=0,000$ untuk kelompok kelompok kontrol (X2). Analisis statistik untuk data tidak berdistribusi normal menggunakan uji perbedaan Mann whitney. Jika nilai $p<0,05$ menunjukkan terdapat perbedaan bermakna antar

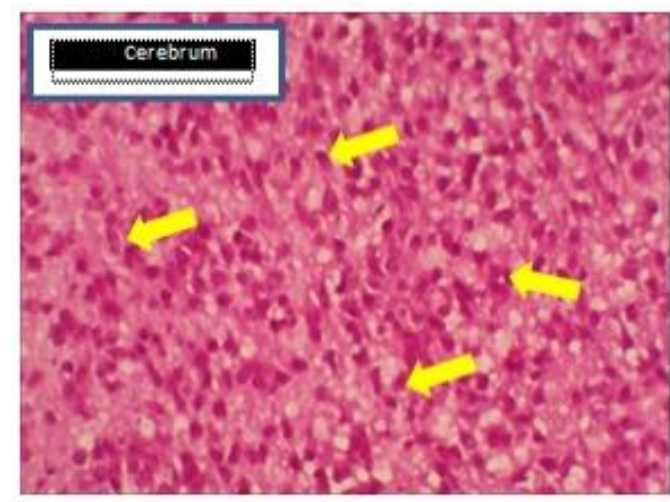

kelompok. Hasil analisis uji Mann whitney disajikan pada tabel di bawah ini:

Tabel 9. Hasil uji Mann whitney jumlah sel neuron otak Mus musculus baru lahir.

\begin{tabular}{cc}
\hline Jumlah \\
sel neuron
\end{tabular}

*Berbeda bermakna (signifikansi $\mathrm{p}<0,05$ )

Diketahui bahwa hasil uji Mann whitney menunjukkan ada perbedaan bermakna jumlah sel neuron antara kelompok perlakuan dan kontrol di otak $(p=0,000)$.

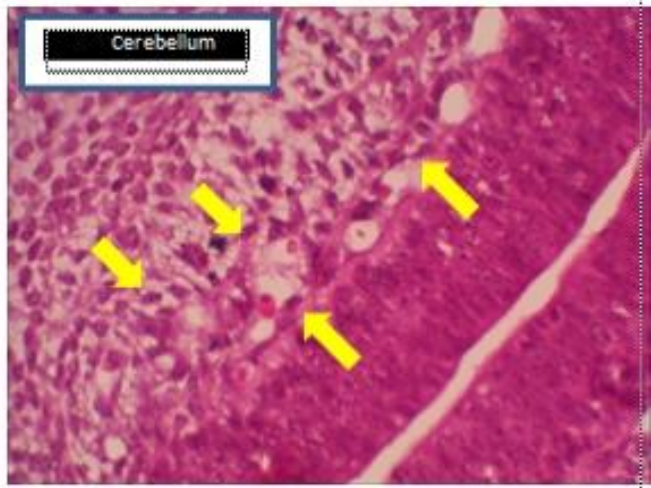

Gambar 4. jumlah sel neuron cerebrum dan cerebellum Mus musculus pada kelompok kontrol (X2).
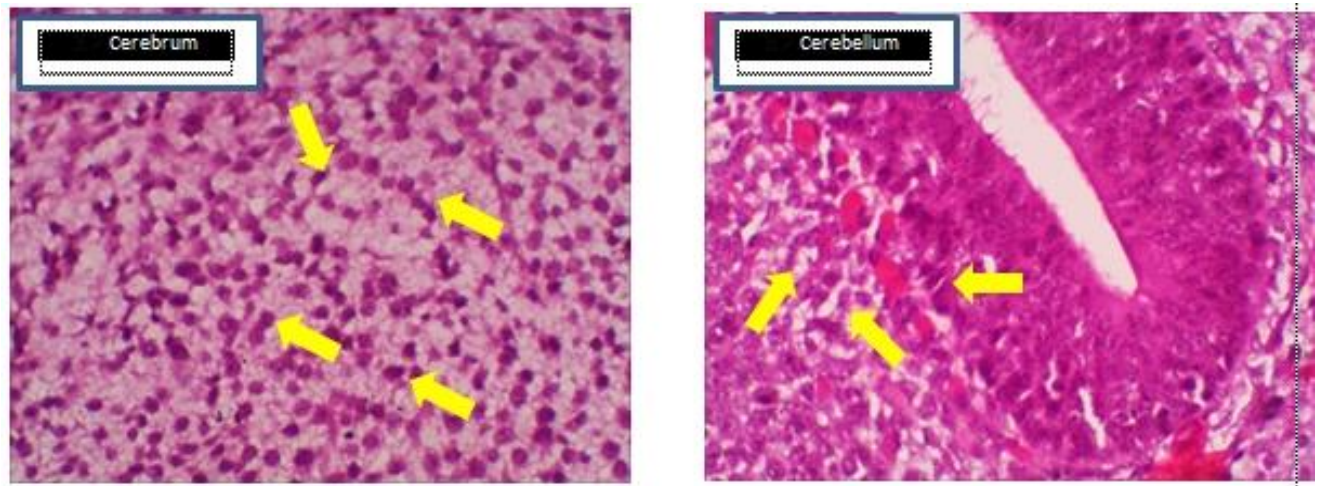

Gambar 5. jumlah sel neuron cerebrum dan cerebellum Mus musculus pada kelompok perlakuan (X1).

\section{PEMBAHASAN}

Berdasarkan dari hasil penelitian bahwa adanya perbedaan yang signifikan antara jumlah sel neuron di cerebrum dan cerebellum, dimana pada kelompok kehamilan dewasa lebih tinggi jumlah sel neuronnya dibandingkan dengan remaja.

Perkembangan sistem saraf pusat (SSP) adalah serangkaian kejadian yang kompleks yang meliputi proliferasi sel, 
diferensiasi, migrasi, perpanjangan proses, dan pembentukan spesifik koneksi antara berbagai jenis sel, seperti kontak sinaptik antara neuron dan kontak antara neuron dan glia (Koziol et al, 2013). Ada banyak faktor yang mempengaruhi tumbuh kembang otak. Beberapa faktor antara lain: poor maternal diet, food restriction, maternal mental illness, konsumsi alcohol, stimulasi dan obat-obatan, infeksi dan paparan terhadap toksin lingkungan (Koffman, 2014). Pembentukan sel neuron di otak juga dipengaruhi oleh beberapa hal, antara lain prenatal stres yang dapat menurunkan berat hipokampus (Musazzi et al, 2010).

Hewan prapubertas menampilkan respon stres hormon yang lebih besar dibandingkan dengan yang dewasa, yang diukur dengan hormon adrenocorticotropin plasma (ACTH) dan tingkat kortikosteron, (Perez-Nievas et al, 2007; Juananda, 2015).

Pra pubertas dan pertengahan remaja hewan (30-50 hari usia) dapat mengambil dua kali lebih lama untuk kembali ke normal setelah stressor psikologis dan/ atau fisiologis dibandingkan dengan dewasa mereka (70 hari usia) (Barros et al, 2006).

Otak secara khusus rentan terhadap stres prenatal dan kekurangan gizi karena perkembangannya yang panjang (Bale,
2015). Sebuah studi menunjukkan bahwa stres prenatal memang mempengaruhi morfologi otak anak, ditunjukkan dengan volume jaringan yang berkurang pada kedua, tingkat makroskopik dan mikroskopik

Diantara aktivasi kronis dari respon stres selama kehamilan telah terbukti berpotensi merusak manusia dan hewan percobaan. Beberapa ulasan telah menunjukkan bahwa stres sebelum melahirkan memiliki efek jangka panjang pada hasil fisik dan perilaku dari hewan pengerat, primata, dan keturunan manusia. Pengaruh stres prenatal telah diperiksa sebagian besar dalam model tikus, dan perubahan utama yang dilaporkan termasuk disfungsi perilaku, kemampuan belajar, dan perkembangan motorik dan gangguan dari hipotalamushipofisis-adrenal (HPA) bersama dengan perubahan fungsi dan morfologi otak (Popoli et al, 2013).

Jumlah sel neuron dapat dipengaruhi oleh stress pada masa kehamilan sehingga meningkatkan aktfitas HPA aksis dan meningkatkan kadar $\mathrm{CRH}$ dan aktifitas glukokortikoid yang menurunkan aktifitas growth hormone factors, GH dan IGF-1 serta menurunkan ekspresi 11ß-HSD2. Aktifitas grouth hormone factors, $\mathrm{GH}$ dan IGH-1 yang menurunkan aktifitas proliferasi, diferensiasi dan lain-lain 
Perbedaan Jumlah Sel Neuron Cerebrum dan Cerebellum Mus musculus pada Kehamilan... Tri Purwanti, Widjiati, Muhammad Miftahussurur

(Murray and Holmes, 2011; Eiland and Romeo, 2013)

Stress kronik menginduksi perubahan endokrin (HPA-axis), neurotransmitter, dan sistem memori otak, termasuk hippocampus, amygdala, dan Prefrontal cortex (PFC) yang bertahan sepanjang rentang hidup serta meningkatkan jumlah corticotropin releasing factor (CRF) hipotalamus yang dilepaskan ke kelenjar hipofisis anterior, merangsang sekresi ACTH di hipofisis anterior dan menghasilkan produksi glucocorticoid (GC) di kelenjar adrenal (Sullivan, 2010).

Pada Mus musculus remaja terjadi respon stress akibat kesiapan untuk bereproduksi dengan adanya jantan yang siap kawin sehingga terjadi stress kronik yang berdampak pada neuroendokrin.

\section{KETERBATASAN PENELITIAN}

Keterbatasan pada penelitian ini adalah penelitian ini hanya mengasumsikan perbedaan jumlah sel neuron anak mencit saat lahir, tetapi belum melakukan pemeriksaan ACTH dan kortisol terkait stress pada maternal.

\section{KESIMPULAN}

Terdapat perbedaan Jumlah sel neuron cerebrum dan cerebellum baru lahir dari kebuntingan induk Mus musculus dewasa, hal ini terbukti bahwa jumlah sel neuron pada cerebrum dan cerebellum pada kehamilan mencit dewasa lebih tinggi dibandingkan dengan jumlah sel neuron pada cerebrum dan cerebellum pada kehamilan daripada remaja.

\section{DAFTAR PUSTAKA}

Akbar B, 2010. Tumbuhan Dengan Kandungan Senyawa Aktif Yang Berpotensi Sebagai Bahan Antifertilitas. Jakarta: Adabia Press pp 6-7.

Bale TL, 2015. Epigenetic and transgenerational reprogramming of brain development. Nat Rev Neurosci. 16(6): 332-344.

Barros VG, Duhalde-Vega M, Caltana L, Brusco A, Antonelli MC, 2006. Astrocyte-neuron vulnerability to prenatal stress in the adult rat brain. Journal of Neuroscience Research. 83(5): 787-800.

Curtis AC, 2015. Definiting adolesence. Journal of adolescent and family health. 7(2): 1-40.

Eiland L and Romeo RD, 2013. Stress and the developing adolescent brain. Neuroscience. 249:162-171.

Fitria L, Mulyati, Tiraya CM, Budi AS, 2015. Profil Reproduksi Jantan Tikus (Rattus norvegicus Berkenhout, 1769) Galur Wistar Stadia Muda, 
Pradewasa, dan Dewasa. 7(1): 29-

36.

Hewitt CD, Innes DJ, Savory J and Willis MR, 1989. Normal biochemical and hematological values in New Zealand white rabbits. Clinical Chemistry. 35(8): 1777-1779.

Ihedioha JI, Ugwuja JI, Noel-Uneke OA, Udeani IJ and Daniel-Igwe G, 2012. Reference values for the haematology profile of conventional grade outbred albino mice (Mus musculus) in Nsukka, Eastern Nigeria. Animal Research International. 9(2): 1601-1612.

Juananda D, Sari DCR, Prakoso D, Arfian N, Romi M, 2015. Pengaruh stress kronik terhadap otak: kajian biomolekuler hormone glukokortikoid dan regulasi brain derived neurotropic factor (BDNF) pasca stress di cerebellum. Jurnal ilmu kedokteran. 9(2): 65-70.

Kawakita T, Wilson K, Grantz KL, Landy HJ, Huang CC, Gomez-Lobo V, 2016. Adverse maternal and neonatal outcomes in adolescent pregnancy. J Pediatr Adolesc Gynecol. 29(2): 130-136.

Kirbas A, Gullerman HC, Daglar K, 2016. Pregnancy in adolescence: is it an obstetrical risk?. North American Society for Pediatric and Adolescent Gynecology. Published by Elsevier Inc.

Koffman O, 2014. Fertile bodies, immature brains?: A genealogical critique of neuroscientific claims regarding the adolescent brain and of the global fight against adolescent motherhood. Soc Sci Med. 143: 255-261.

Koziol LF, Budding D, Andreasen N, D’Arrigo S, Bulgheroni $S$ et al, 2013. Consensus Paper: The Cerebellum's role in movement and cognition. Cerebellum. 13(1): 151-177.

Lefwitch HK and Alves MV, 2017. Adolescent pregnancy. Pediatr Clin North Am. 64(2): 381-388.

Murray PS and Holmes PV, 2011. An overview of Brain-Derived Neurothrophic Factor and Implications for Excitotoxic Vulnerability in the Hippocampus. International Journal of Peptides. 20:1-12.

Musazzi L, Milanese $M$, Farisello $P$, Zappettini S, Tardito D, Barbiero VS, 2010. Acute stress increases depolarization-evoked glutamate release in the rat prefrontal/ frontal cortex: the dampening 
Perbedaan Jumlah Sel Neuron Cerebrum dan Cerebellum Mus musculus pada Kehamilan... Tri Purwanti, Widjiati, Muhammad Miftahussurur

action of antidepressants. PloS ONE. 5(1): e8566.

Pérez-Nievas BG, Garcia-Bueno B, Caso JR, Leza JC, 2007. Corticosterone as a marker of susceptibility to oxidative/ nitrosative cerebral damage after stress exposure in rats. Psychoneuroendocrinology. 32(6): 703-711.

Popoli M, Yan Z, McEwan BS, Sanacora G, 2013. The Stressed synapse: the impact of stress and glucocorticoids on glutamate transmission. Nat Rev Neuroscience. 13(1): 22-37.

Sarwono, S. 2011. Psikologi remaja. Jakarta: PT. Raja Grafindo.

Sengupta $P, 2013$. The laboratory rat: Relating its age with human's. International Journal of Preventive Medicine. 4(6): 624630.

Sullivan EV, 2010. Cognitive fungtion of cerebellum. Neuropsychol Rev. 20(3): 227-228. 